\title{
Typpi- ja valkuaisomavaraisuuden lisääminen palkokasveja tehokkaasti hyödyntämällä (MoniPalko)
}

Timo Sipiläinen ${ }^{1}$, Hannu Känkänen ${ }^{1}$, Erja Huusela-Veistola ${ }^{1}$, Heikki Jalli ${ }^{1}$, Marja Jalli ${ }^{1}$, Antti Hannukkala $^{1}$, Arja Nykänen ${ }^{1}$, Riitta Lemola ${ }^{1}$, Harri Turunen ${ }^{1}$, Kauko Koikkalainen ${ }^{1}$, Fred Stoddard ${ }^{2 a}$, Aila Vanhatalo $^{2 \mathrm{~b}}$ ja Maritta Kymäläinen ${ }^{3}$

${ }^{1}$ MTT, 31600 Jokioinen, etunimi.sukunimi@mtt.fi

${ }^{2}$ Helsingin yliopisto a) Soveltavan biologian ja b) Kotieläintieteen laitos, PL 27, 00014 Helsingin yliopisto, etunimi.sukunimi@helsinki.fi

${ }^{3}$ Hämeen ammattikorkeakoulu, PL 230, 13101 Hämeenlinna, maritta.kymalainen@hamk.fi

\section{Tiivistelmä}

Vuonna 2008 lannoitekustannukset nousivat jyrkästi ja niiden osuus viljanviljelyn kustannuksista oli noin 20 \% eli lähes yhtä suuri kuin pääomakustannus. Sittemmin niin energian kuin kasvinviljelytuotteidenkin hinnat ovat laskeneet, mutta viljanviljelyn hehtaaria kohti kuluttamasta energiasta lähes puolet käytetään lannoitteisiin. Lannoitetypen saatavuuden riippuvuus uusiutumattomista energialähteistä aiheuttaa sen, että typen saatavuus on myös huoltovarmuuskysymys. Tehokas keino typpilannoitustarpeen vähentämiseksi on ilmakehän typpeä sitovien palkokasvien käyttö niin karkea- kuin valkuaisrehun tuotannossa ja viherlannoitteena. Nykyistä laajempi palkoviljojen viljely kasvattaisi Suomen valkuaisomavaraisuutta.

Tutkimus on jatkoa aiemmille palkokasvien hyväksikäyttöä tutkineille hankkeille. Aiempien ja käynnissä olevien muiden sekä tämän tutkimuksen tuottamaa biologista ja teknistä tietoa yhdistetään käsillä olevan hankkeen talousosiossa.

Tutkimuksen tavoitteena on

1. Kehittää ja mallintaa uusimpaan tutkimustietoon perustuvia viljelymenetelmiä ja -järjestelmiä, joissa palkokasvit ovat osa taloudellista ja ravinteiden käytön kannalta tehokasta tuotantoa. Tavoitteena on kehittää taloudellisesti ja ekologisesti nykyistä kestävämpiä viljelyjärjestelmiä Suomen olosuhteisiin.

2. Etsiä keinoja, joilla parannetaan palkoviljojen sadontuottoa ja lisätään niiden viljelyvarmuutta sekä laajennetaan kasvilajivalikoimaa.

3. Kehittää keinoja erityisesti palkokasvien sitoman typen hyväksikäytön tehostamiseksi väkilannoitetypen korvaajina.

4. Siirtää olemassa olevaa ja hankkeessa tuotettavaa tutkimustietoa käytännön toimijoille heidän omaan toimintaansa sovellettavaksi.

Tutkimuksessa käytetään taloudellista mallintamista ja tuotantomalliratkaisuja sekä kenttäkoeja analyysimenetelmiä viherlannoituksen käytön tehostamiseen, palkoviljojen viljelytekniikan parantamiseen sekä laji- ja lajiketutkimukseen sovellettuna. Palkokasvien typensidontapotentiaalia ja sitä kautta syntyvää typpilannoitteiden korvaamismahdollisuutta arvioidaan myös koko maan tasolla.

Tutkimus toteutetaan monitieteisenä tutkimuksena pääasiassa MTT:ssa talous- ja kasvintuotannontutkimuksen yhteistyönä sekä yhdessä Helsingin yliopiston soveltavan biologian ja kotieläintieteen laitoksen kanssa. Viherlannoituskokeiden biokaasuosio suoritetaan yhteistyössä Hämeen Ammattikorkeakoulun kanssa. Kasvintuotannon kokeet suoritetaan Jokioisilla ja Mikkelissä. MTT Taloustutkimus vastaa taloudellisen mallinnuksen suorittamisesta.

Tutkimus aloitettiin 1.4.2009 ja hanke jatkuu vuoden 2012 maaliskuun loppuun saakka.

Avainsanat: biologinen typensidonta, viherlannoitus, viljelyjärjestelmä, kasvinsuojelu, herne, härkäpa$\mathrm{pu}$ 


\section{Johdanto}

Vuonna 2008 lannoitekustannukset nousivat jyrkästi ja niiden osuus viljanviljelyn kustannuksista oli noin 20 \% eli lähes yhtä suuri kuin pääomakustannus. Sittemmin niin energian kuin kasvinviljelytuotteidenkin hinnat ovat laskeneet, mutta viljanviljelyn hehtaaria kohti kuluttamasta energiasta lähes puolet käytetään lannoitteisiin. Lannoitetypen saatavuuden riippuvuus uusiutumattomista energialähteistä aiheuttaa sen, että typen saatavuus on myös huoltovarmuuskysymys. Tehokas keino väkilannoitetypen käyttötarpeen vähentämiseksi on ilmakehän typpeä sitovien palkokasvien käyttö karkea- ja valkuaisrehun tuotannossa sekä myös viherlannoitteena. Nykyistä laajempi palkoviljojen viljely kasvattaisi samalla Suomen valkuaisomavaraisuutta. Tilakohtaisesti suunniteltu palkokasvien käyttö viljelykierrossa ja yleensä ravinteiden käytön tehostaminen vähentäisi myös maatilojen aiheuttamaa ravinnekuormitusta vesistöihin ja ilmaan.

Palkokasvit hyödyntävät ilmakehän typpeä biologisen typensidonnan kautta. Niiden avulla voidaan väkilannoitetypen käyttöä vähentää merkittävästi ja siten säästää fossiilisia energiavaroja. Palkokasvit sekä sitovat ilmasta valtaosan itse tarvitsemastaan typestä että tuottavat samalla typpeä myös maaperään viljelykierron seuraaville kasveille ja parantavat maan rakennetta. Ne ovat erinomaista rehua sekä tuontisoijan korvaajina että karkearehuna. Myös kasvisruokavaliossa palkokasvit korvaavat lihaa ja sisältävät paljon ravinto-, kivennäis- ja hivenaineita. Se, miten suuri kunkin palkokasvin typensidontateho lopulta on, on Suomen oloissa yhä tutkimatta muiden kuin niittonurmissa viljeltävän puna-apilan osalta (Nykänen 2008). Tutkimus on haasteellista, koska palkokasvit ottavat osan käyttämästään typestä maaperästä mineralisoituvista typpivaroista, joten niiden kokonaistyppimäärä ei ole kokonaan ilmasta peräisin. Ratkaisu palkokasvien typensidonnan määrittämiseen on ${ }^{15} \mathrm{~N}$-isotoopin käyttäminen, kuten puna-apilan osalta on tehty (Nykänen 2008). Samaa menetelmää käytetään tässä tutkimuksessa myös muiden palkokasvien typensidonnan mittaamiseen.

Tällä hetkellä Suomen valkuaisrehuomavaraisuus on alle $20 \%$, mikä on kymmenisen prosenttia alhaisempi kuin Euroopassa keskimäärin. Se on erittäin alhainen huoltovarmuuden kannalta. Palkokasvien käyttö Suomessa on ollut suhteellisen vähäistä, vaikka niiden hyödyt tunnetaan ja potentiaalinen kasvilajivalikoima Suomessakin on laaja. Hintasuhteiden vaihdellessa kiinnostus palkokasveja kohtaan on kuitenkin kasvanut, ja apilapitoisten nurmien viljely on lisääntynyt selkeästi. Apuna viljelyn edistämisessä ovat olleet MMM:n ja MTT:n rahoittamat laajat tutkimukset, kuten "Puna-apila tehokkaasti luomumaidoksi 2003-2006", laajat puna-apilakokeet 1990-luvun alussa sekä EU:n FP5hanke Legsil "Nurmipalkokasvisäilörehuihin perustuva tuotantopanoksia ja ympäristöä säästävä kotieläintuotanto" (Vanhatalo ja Topi-Hulmi 2007, Mela 2004, Syrjälä-Qvist 2001). Viime aikoina kiinnostus palkoviljoihin, kuten kotimaisen härkäpavun tuottamiseen on myös alkanut kiinnostaa rehuteollisuutta. Koska kansainvälinen yhteistyö tällä alueella on lisääntymässä, myös kotimaista asiantuntijuutta tarvitaan lisää.

Herne on monessa mielessä hyödyllinen peltokasvi sekä hyvä rehuvalkuaisen ja ravinnon lähde. Viimeksi herneestä on saatu myönteisiä tuloksia Kovaherne-hankkeessa, jossa herne mm. todettiin hyväksi rehuksi eri kotieläimille (Koetoiminta ja Käytäntö 13.6.2005, herneen teemanumero). Hyvin onnistuessaan herne on kilpaillut menestyksekkäästi kannattavuudessa viljojen kanssa, mutta viljelyn laajeneminen edellyttää viljelyvarmuuden lisäämistä. Lako vaikeuttaa herneen puintia ja kuivatusta ja lisäksi sadon laatu kärsii. Edelleen herneen viljelyvarmuutta heikentävät rikkakasvit, kasvitaudit ja tuhoeläimet, jotka pienentävät satoa ja heikentävät tai pilaavat sadon laadun.

Kiinnostus härkäpavun viljelyyn on lisääntynyt. Teollisuus on kiinnostunut härkäpavusta valkuaisenlähteenä. Härkäpavun viljelyvarmuutta ei ole Suomessa juurikaan tutkittu. Linuroni-herbisidien on arveltu sopivan nykyisistä torjunta-aineista myös härkäpavulle, mutta MTT:n Kasvintuotannon tutkimuksessa syksyn 2008 olosuhteissa tehdyssä alustavassa astiakokeessa linuroni vioitti härkäpavun taimia. Toisaalta ei tiedetä, minkä tasoinen vioittuminen on hyväksyttävissä rikkakasviongelman poistamiseksi. Mahdollisina ratkaisuina palkokasvien tuotannon ongelmiin voivat olla palkokasvien seosviljelyn uudet vaihtoehdot sekä uusien lajien ja lajikkeiden viljelyyn ottaminen.

Palkokasveista jää maahan typpeä viljelykierron seuraaville kasveille, mutta tätä prosessia on vaikea hallita, koska kyseessä ovat biologiset reaktiot (Nykänen 2008, Känkänen ym. 1998, 1999). Tähänastisen kokemuksen ja tutkimustiedon mukaan ravinteiden hallinnassa avainasemassa ovat viljelytekniset toimenpiteet, kuten maan muokkaus oikeaan aikaan (Känkänen ym. 1998, 1999), monivuo- 
tisten kasvilajikkeiden ja lajien oikea valinta siten, että kasvustot talvehtivat (Hakala ja Jauhiainen 2007) ja se, että seoskasvustojen kasvilajien (esim. heinä ja apila) välinen kilpailu on tasapainossa. Tasapainoisesta kasviyhteisöstä saadaan varmempi sato ja tehokkaampi ravinteiden otto, jolloin huuhtoumavaara on pieni. Peltoon jäävien kasvien lajikoostumus vaikuttaa kasvimassan hiilityppisuhteeseen ja sitä kautta typen mineralisoitumiseen (Jensen ym. 2005) ja siten myös kasvien käytettävissä olevaan sekä toisaalta huuhtoutumiselle alttiina olevaan typpeen. Typen käyttäytymistä eri oloissa ja eri kasviseoksissa voidaan mallintaa (esim. puna-apilanurmien osalta käytetty simulaatiomalli CoupModel, Nykänen 2008), mutta työ on vasta alussa ja lisää tutkimustietoa tarvitaan.

Palkokasvien käyttö pelkkänä viherlannoituksena on tehokas tapa tuottaa typpeä kasvien käyttöön (Känkänen ym. 2001). Tämä menetelmä kuitenkin jättää satoa tuottamattomia vuosia pelloille, jollei niitä pystytä hyödyntämään lannoitusvaikutuksen lisäksi myös esim. eläinten rehuna. Kiinnostus viherlannoitukseen on kuitenkin lisääntynyt myös tavanomaisilla tiloilla, koska typpilannoitusvaikutuksen lisäksi viherlannoitusnurmi parantaa maan rakennetta. Huono maan rakenne onkin alkanut muodostua ongelmaksi monilla tiloilla. Bioenergian tuotannon lisääntyessä ja tietotaidon karttuessa, on viherlannoitusbiomassan käyttö metaanin tuotantoon tullut vaihtoehdoksi, joka voisi parantaa viherlannoituksen kannattavuutta, jos metaanienergia voidaan hyödyntää tilalla. Saksalaisten ja ruotsalaisten tutkimusten mukaan mädätetyn vihermassan lannoitusvaikutus paranee ja huuhtoutumisriskit vähenevät, kun vihermassa kaasutetaan ja mädäte levitetään pellolle silloin, kun kasvit sitä pystyvät parhaiten hyödyntämään (Stinner ym. 2008, Möller ja Stinner 2008, Båth ym. 2008). Vaikka viherlannoituskasvien lannoitus- ja huuhtoutumisvaikutuksia on Suomessakin tutkittu (mm. Känkänen ym. 2001), tutkimuksia tulisi syventää typen hyödyntämisen tehostamiseksi sekä tavanomaisissa että luonnonmukaisissa viljelyjärjestelmissä.

\section{Tutkimuksen tavoitteet}

Hankkeen päätavoitteena on parantaa biologisen typensidonnan hyötysuhdetta, maatilojen ravinneomavaraisuutta sekä maatalouden valkuaisomavaraisuutta. Omavaraisuuden kasvattamisen tavoitteena on, että toimenpiteet voidaan suorittaa taloudellisesti kannattavasti ja suomalaisen kasvi- ja kotieläintuotannon kilpailukykyä kehittäen. Hankkeessa keskitytään typen ja erityisesti biologisen typensidonnan hyödyntämiseen karkea- ja valkuaisrehun tuotannossa. Näkökulma on uusi, sillä aiemmin vaihtoehtoina ovat yleensä olleet joko luomu- tai tavanomainen tuotanto, mutta tässä tutkimuksessa myös typensidontaa hyödyntävät tavanomaiset viljelyjärjestelmät ovat kiinnostuksen kohteena.

Tavoitteeseen pyritään neljän osatavoitteen kautta, joista ensimmäinen on taloudellinen, toinen sekä kolmas biologisia ja viljelyteknisiä ja neljäs tiedonsiirtoa palveleva:

1. Kehitetään mallinnuksen avulla uusimpaan tutkimustietoon perustuvia viljelymenetelmiä ja -järjestelmiä, joissa palkokasvit ovat osa taloudellista ja ravinteiden käytön kannalta tehokasta tuotantoa. Tavoitteena on kehittää taloudellisesti ja ekologisesti nykyistä kestävämpiä viljelyjärjestelmiä Suomen olosuhteisiin.

2. Etsitään keinoja, joilla parannetaan palkoviljojen sadontuottoa ja lisätään niiden viljelyvarmuutta sekä laajennetaan kasvilajivalikoimaa. Tämä tapahtuu mm. ekologisen ja kemiallisen kasvinsuojelun kehittämisen, geenivarojen hyödyntämisen sekä seosviljelyn ja korjuuajan täsmentämisen avulla.

3. Kehitetään keinoja biologisen typensidonnan hyväksikäytön tehostamiseksi kasvinviljelyssä. Palkoviljojen, nurmipalkokasvien ja viherlannoituskasvustojen typensidonnan tehokkuus Suomessa selvitetään, koska tietoa ei ole ja se on oleellisen tärkeä esimerkiksi ravinnetaseiden laskennassa. Lisäksi selvitetään yksivuotisten puna-apilapitoisten nurmien viherlannoitusvaihtoehtoja väkilannoitetypen osittaisina korvaajina viljantuotannossa.

4. Siirretään olemassa olevaa ja hankkeessa tuotettavaa tutkimustietoa käytännön toimijoille heidän omaan toimintaansa sovellettavaksi. Tämä tapahtuu alueellisten, valtakunnallisten ja kansainvälisten kehittämishankkeiden kautta. Aiheina ovat mm. luomuvalkuaisrehun tuotannon lisääminen, viherlannoituksen ympäristöystävällinen hyödyntäminen luomu- ja tavanomaisilla kasvinviljelytiloilla sekä palkokasvien tehokas hyödyntäminen nurmirehuna Luoteis-Venäjän karjataloudessa. 


\section{Osahankkeiden odotetut tulokset}

Tutkimus koostuu kolmesta tutkimusosiosta eli työpaketista, jotka ovat typensidonnan taloudellinen hyödyntäminen, palkoviljantuotannon viljelyvarmuuden parantaminen sekä palkokasvien typensidonnan määrittäminen ja viherlannoituksen käytön tehostaminen.

Tutkimusosion yksi odotetaan tuottavan tietoa käytännöistä, joilla omavaraisuutta typen käytön suhteen voidaan kustannustehokkaimmin parantaa, sekä analyyseja siitä, mitkä olisivat väkilannoitetypen korvaamisen taloudelliset edellytykset erilaisten hintasuhteiden vallitessa. Typen käytön tehostuminen antaa mahdollisuuden myös tuotannon kannattavuusedellytysten parantamiseen. Palkoviljojen viljelyn kehittäminen tarjoaa mahdollisuuden myös valkuaisrehuomavaraisuuden kasvattamiseen ja siten huoltovarmuuden lisäämiseen.

Tutkimusosion kaksi tuloksena saadaan ohjeistukset tukikasvilajien käytöstä herneen viljelyssä, tieto Suomen oloihin soveltuvista uusista palkoviljalajikkeista sekä niille sopivista kestävistä kasvinsuojeluratkaisuista. Kokeista saatavat tulokset ja kirjallisuudesta löytyvä tieto kootaan koulutus- ja tietopaketiksi, joka parantaa edellytyksiä tuottaa palkoviljoja kannattavasti. Hankkeen lopputuloksena palkoviljojen viljelyvarmuus paranee, minkä ansiosta teollisuus saa hyvälaatuista raaka-ainetta riittävästi vuosittain. Tietoja hyödynnetään myös hankkeen mallinnusosiossa.

Työpaketti kolme koostuu kahdesta osiosta, joista ensimmäisessä määritetään typensidonnan määrää eri palkokasveilla Suomen oloissa ja toisessa mahdollisuuksia tehostaa viherlannoituksen käyttöä. Ensimmäisen osion tuloksena saadaan eri palkokasvien typensidonnan määrät Suomen olosuhteissa, joka palvelee suoraan tiloilla tehtäviä ravinnetaselaskelmia. Lisäksi annetaan ohjeita typensidonnan määrän lisäämiseen ja sitä kautta palkokasvien esikasviarvon määrittämiseen ja parantamiseen. Toisen osion tuloksena_saadaan suositukset viherlannoituskasvustojen käytöstä niin, että niiden lannoitusvaikutus seuraavalle kasville on mahdollisimman hyvä, huuhtoutumisriskit vesistöihin pienet ja ne ovat taloudellisesti kannattavia viljelytoimenpiteitä. Tietoja hyödynnetään hankkeen talousosiossa. Ravinteikkaan mädätteen tuottamisen ohella biokaasutuskoetoiminnalla saadaan käytännön tietoa apilabiomassan biokaasutettavuudesta jatkuvatoimisessa prosessissa. Tuloksena saadaan prosessin hallinnan kannalta tärkeää prosessitietoa kuin myös apilabiomassasta saatavan biokaasun määrä ja laatu $\left(\mathrm{CH}_{4} \mathrm{ja}\right.$ $\mathrm{CO}_{2}$-pitoisuudet) ja täten sen energia-arvo. Kokemukset ja tulokset ovat suoraan hyödynnettävissä esim. suunniteltaessa apilabiomassan biokaasutusta tilatasolla.

Tutkimuksen tuloksia julkaistaan lehtikirjoitusten ja esitelmien muodossa tutkimuksen edetessä. Tutkimus tuottaa toimenpidesuosituksia käytännön viljelyyn sekä poliittisiksi ohjauskeinoiksi. Tuotoksena syntyy myös koulutusmateriaalia biologisen typensidonnan tehokasta käyttöä varten.

\section{Hankkeen toteuttajat}

Työpaketin yksi tutkimusryhmän muodostavat MMM Harri Turunen, MMM Kauko Koikkalainen ja MMT Timo Sipiläinen. Taloustarkastelut pohjautuvat tutkimushankkeen muiden jäsenten biologiseen ja tekniseen asiantuntemukseen sekä aiempiin ja uusiin koetuloksiin. Professori Aila Vanhatalo Helsingin yliopistolta (Kotieläintieteen laitos) toimii kotieläinruokinnan asiantuntijana olemassa olevan tutkimusaineiston hyödyntämiseksi mallinnuksessa.

Työpaketin kaksi tutkijat ovat FT Erja Huusela-Veistola, MMM Heikki Jalli, MMM Marja Jalli, MMM Hannu Känkänen, MMT Fred Stoddard ja FM Lauri Jauhiainen.

Työpaketin kolme tutkijoina toimivat MMT Arja Nykänen ja MMM Riitta Lemola kasvintuotantotutkimuksissa sekä TkT Maritta Kymäläinen HAMK:sta biokaasutuksen osalta. 


\section{Kirjallisuus}

Båth, B. \& Elfstrand, S. 2008. Use of Red Clover-Based Green Manure in Leek Cultivation. Biological Agriculture and horticulture. 25: 269-286.

Hakala, K. \& Jauhiainen, L. 2007. Yield and nitrogen concentration of above- and below-ground biomasses of red clover cultivars in pure stands and in mixtures with three grass species in northern Europe. Grass and Forage Science 62, 312-321.

Jensen, L.S., Salo, T., Palmason, F., Breland, T.A., Henriksen, T.M., Stenberg, B., Pedersen, A., Lundström, C. \& Esala, M. 2005. Influence of biochemical quality on C and N mineralisation from a broad variety of plant materials in soil. Plant and soil 273: 307-326.

Känkänen, H., Kangas, A., Mela, T., Nikunen, U., Tuuri, H. \& Vuorinen, M. 1998. Timing incorporation of different green manure crops to minimize the risk of nitrogen leaching. Agricultural and Food Science in Finland 7, 5-6: 553-567.

Känkänen, H., Kangas, A., Mela, T., Nikunen, U., Tuuri, H. \& Vuorinen, M. 1999. The effect of incorporation time of different crops on the residual effect on spring cereals. Agricultural and Food Science in Finland 8, 3:285-298.

Känkänen, H. 2001. Viherkesannot ja aluskasvit viljan viljelyssä: Viljelyjärjestelmät-tutkimuksen loppuseminaari, Jokioinen, 7.3.2001. MTT:n julkaisuja. Sarja B 25: 41 p. +1 app. http://mttinfo.mtt.fi/bsarja/pdf/bsarja25.pdf

Mela, T. 2003. Red clover grown in a mixture with grasses : yield, persistence and dynamics of quality characteristics. Agricultural and Food Science in Finland 12, 3-4: 195-212.

Möller, K. \& Stinner, W. 2008. Effects of different manuring systems with and without biogasdigestion on soil mineral nitrogen content and on gaseous nitrogen losses (ammonia, nitrous oxides). European Journal of Agronomy 30: 1-16.

Nykänen, A. 2008. Nitrogen dynamics of organic farming in a crop rotation based on red clover (Trifolium pratense) leys. Agrifood Research reports 121. 130 p. (PhD Dissertation)

Stinner, W., K. Möller, K. \& G. Leithold, G. 2008. Effects of biogas digestion of clover/grass-leys, cover crops and crop residues on nitrogen cycle and crop yield in organic stockless farming systems. European Journal of Agronomy 29: 125-134

Syrjälä-Qvist, L. 2001. Professori Liisa Syrjälä-Qvistin juhlaseminaari 1.11.2001.Suomen Nurmiyhdistyksen julkaisu 16.

Vanhatalo, A. \& Topi-Hulmi, M. 2007. Puna-apilaa nurmiin ja ruokintapöydälle: Puna-apila tehokkaasti luomumaidoksi -tutkimushankkeen päätösseminaari 17.4.2007. Suomen Nurmiyhdistyksen julkaisu 25 